\title{
Relationship between vegetation and modern pollen-rain along an elevational gradient on Kilimanjaro, Tanzania
}

\author{
Lisa Schüler, 1,2 Andreas Hemp' and Hermann Behling²
}

\begin{abstract}
Modern pollen-rain studies are crucial for the calibration and interpretation of fossil pollen records. In East Africa, numerous pollen records provide important insights into the impact of human populations and climate change on tropical ecosystems. However, the confident use of fossil pollen data to reconstruct vegetation and climate dynamics requires well-founded knowledge regarding the relationship between pollen deposition and modernday vegetation, which is still deficient for large parts of the African continent and non-existent for the tropical East African Mountains. In this study, we investigated the relationship between vegetation and modern pollen-rain along the elevational gradient of Kilimanjaro. We apply multivariate data analysis to assess the relationship between vegetation and modern pollen-rain and quantify the representativeness of forest zones. We further assessed the taxonomic level needed for differentiation between forest zones based on the modern pollen-rain assemblage, biodiversity patterns and pollen and spore drift. In the montane vegetation of Kilimanjaro, it is sufficient to analyse the pollen-rain on plant family level in order to derive the forest zone of the surrounding vegetation. Along this elevational gradient, pollen and spore dispersal is strongly influenced by regional wind patterns, but their deposition reflects the diversity patterns of the surrounding vegetation. This study represents the first statistical analysis of pollen vegetation relationship along an elevational gradient in Africa. Hence, this paper improves confidence in interpretation of palynological records from the tropical East African Mountains and may refine past climate reconstructions for a more accurate comparison of data and modelling.
\end{abstract}

\section{Keywords}

East Africa, modern pollen-rain, non-metric multidimensional scaling, pollen vegetation relationship, tropical montane forest, vegetation zones

Received 28 November 2013; revised manuscript accepted 10 February 2014

\section{Introduction}

Modern pollen analogues are essential tools for palaeoecological reconstructions (Birks and Birks, 1980; Huntley et al., 2011). The relationship between vegetation and pollen trap data is essential for the calibration of palaeo-records. However, only few of such calibration studies, which quantitatively relate pollen with altitude and climatic parameters, exist. Modern pollen-rain studies in tropical Africa have been carried out to differentiate between different biomes along latitudinal gradients (Elenga et al., 2000b; Jolly et al., 1998; Lebamba et al., 2009; Lézine et al., 2009; Vincens et al., 2006; Watrin et al., 2007) as well as along altitudinal gradients (Bonnefille and Riollet, 1988; Bonnefille et al., 1993; Vincens et al., 1997).

Modern pollen calibration studies along latitudinal and longitudinal gradients in Africa demonstrate that pollen spectra within one particular vegetation zone are more similar to one another than these pollen spectra are to pollen samples from other vegetation zones (Gajewski et al., 2002); furthermore, a good latitudinal correspondence exists between the distribution patterns of pollen in marine surface sediments and the occurrence of the source plants on the adjacent continent (Dupont and Wyputta, 2003; Hooghiemstra et al., 2006).

Pollen-rain vegetation relationships along steep climatic gradients in the Neotropics show that pollen spectra closely reflect the vegetation composition of Amazonian montane forests (Urrego et al., 2011; Weng et al., 2004). The differentiation of pollen spectra from dry forest localities showed the potential of genus-level pollen data to reflect precipitation gradients. The authors also demonstrate that cloud and rainforest compositional changes along elevation gradients are well represented. Niemann et al. (2010) show that a high number of pollen and spore taxa are characteristic for one vegetation type, and that they reflect the altitudinal distribution of genera and families in the modern vegetation.

Additionally, in a modern pollen-rain elevational study from montane forests in western Amazonia, turnover along the elevational gradient provided a strong correlation with changing pollen spectra (Urrego et al., 2011). The authors demonstrate that longdistance pollen dispersal has little importance within the montane forest zone, and the downslope limit of forest taxa was reflected accurately in pollen spectra. However, Urrego et al. (2011) also show that transport of pollen to elevations above the tree line

'University of Bayreuth, Germany
2University of Göttingen, Germany

Corresponding author:

Lisa Schüler, Department of Plant Systematics, University of Bayreuth, 95447 Bayreuth, Germany.

Email: Lisa.Schueler@uni-bayreuth.de 
leads to significant over-representation of arboreal taxa in shrub and grassland environments.

The comparison between pollen-rain and plant distribution, which clarifies the relationship between plant assemblages and pollen deposition, is therefore essential for a more precise vegetation and climate reconstruction, as it identifies taxa that have high correspondence between pollen and plant distribution patterns. Several analyses of modern pollen-rain have yielded transfer functions relating pollen representation to environmental parameters as well as indicator taxa for particular ecosystems (Bush and Rivera, 2001; Gosling et al., 2009; Rodgers and Horn, 1996; Weng et al., 2004). However, the relationship between pollen assemblage and vegetation is not straightforward since differences in pollen production and dispersal cause some plant taxa to be over-represented in pollen records, while others are underrepresented (Jackson and Lyford, 1999; Prentice, 1985; Sugita, 1994; Tauber, 1967).

A major obstacle to progress in tropical palynology is the high diversity of species, and hence, pollen types. Despite this, much work has recently been done to improve the ability to identify fossil pollen from the tropics (Bush and Weng, 2007; Gosling et al., 2013), and much of the potential information in the record is still lost among the 'unknowns' (e.g. Marret et al., 2013). Furthermore, there is a general lack of understanding of the proportional representation of species (Bush and Rivera, 2001).

In the tropical forests of Barro Colorado Islands (Panama), Bush and Rivera (2001) found that wind-pollinated plants are generally over-represented, while animal-pollinated plants are underrepresented.

It is not clear to what degree the pollen assemblages represent local versus regional vegetation. A substantial proportion of pollen deposited in small basins $(<30 \mathrm{~m}$ in diameter), or under a closed canopy, originates from vegetation growing close to the site $(20-30 \mathrm{~m})$, while pollen from a more distant source often overshadows the local signal in large basins $>30-50 \mathrm{~m}$ in diameter (Jackson and Lyford, 1999; Jacobson and Bradshaw, 1981; Prentice, 1985; Sugita, 1993; Tauber, 1967).

Studies of closed canopy sites have shown a strong representation of pollen from non-local $(>100 \mathrm{~m})$ and even distant sources $(>750 \mathrm{~m})$, if non-local vegetation includes an abundance of taxa that produces large quantities of easily dispersed pollen (Calcote, 1995; Jackson and Kearsly, 1998; Jackson and Wong, 1994; Sugita, 1994). Upslope transport of pollen of wind-pollinated species (e.g. Alnus, Ulmus, Myrica and Quercus) is evident in the sparsely vegetated montane samples from Panama and Costa Rica (Bush, 2000). However, the corresponding downslope transport of these prolific pollen producers is masked by local pollen production.

In the Congo Basin, Elenga et al. (2000a) suggest that the pollen-rain and floristic composition of the vegetation are not linked to altitudinal or precipitation gradients but to hygromorphy and soil type. The results propose that only a few taxa (Symphonia globulifera, Uapaca, Hallea, Anthostema, Dialum and Sapotaceae) show a good correlation between plant cover and pollen abundance. Arboreal taxa dominate the pollen-rain, and the plant diversity is poorly reflected. The results by Elenga et al. (2000a) also propose that in dense lowland rainforest, most pollen grains only travel a distance of $20-50 \mathrm{~m}$.

The studies of Lebamba et al. (2009) and Reese and Liu (2005), which focused on African (Cameroon, Gabon and Congo) and central Andean forests, highlight the potential of modern pollen data to accurately predict present-day vegetation in lowland and montane forest ecosystems.

Biomes reconstructed from modern pollen data (Prentice et al., 1996) accurately reflect the broad features in the vegetation map. For the tropical rainforest biome of South America, $85 \%$ of the sites accurately reflect the potential vegetation (Marchant et al., 2009).
In the montane forests of south-west Uganda, a close relationship was not always observed between the modern pollen-rain and present-day vegetation (Marchant and Taylor, 2000). The subsequent reinterpretation of the Holocene pollen record of the Mubwindi Swamp, SW Uganda, showed that the suggested dominance of Olea (Oleaceae) and Podocarpus (Podocarpaceae) around the swamp was erroneous (Marchant and Taylor, 1998; Marchant et al., 1997). Also, taxa such as Celtis (Cannabaceae), Ericaceae, Faurea (Proteaceae), Hagenia (Rosaceae), Macaranga (Euphorbiaceae), Nuxia (Stilbaceae), Olea (Oleaceae), Podocarpus (Podocarpaceae) and Schefflera (Araliaceae) were probably significantly less important components of the surrounding vegetation over the late Holocene than indicated by their pollen record.

In our study, we address the following questions: (1) how are the different plant taxa represented in the modern pollen-rain and why? (2) which taxonomic level is necessary to distinguish between the different forest zones observed in the vegetation (after Hemp, 2006a)? (3) are the biodiversity patterns of the modern vegetation reflected in the pollen-rain? and (4) what pollen drift effects do we observe by investigating and quantifying the modern pollen-rain-vegetation relationship along an elevational gradient on the southern slope of Kilimanjaro between 1900 and $3200 \mathrm{~m}$ a.s.l. (above sea level). Such a relationship between the vegetation composition and pollen-rain is essential for the calibration of available and future palaeo-records from Kilimanjaro (Schüler, 2013; Schüler et al., 2012) as well as in regions with similar vegetation composition. Multidimensional scaling (MDS) was used in early palynological studies to examine changes in pollen assemblages (Prentice, 1980).

By comparing modern pollen and vegetation inventory data of plots at 100-m elevation intervals, we investigate the relationship between vegetation cover and pollen-rain. For the Neotropics, Punyasena (2008) shows that plant family level is sufficient for palaeo-environmental reconstruction across the range of several different tropical regions. Since this so far has not been shown for smaller scale ecosystems and the identification of tropical pollen grains to a generic or species level remains difficult (e.g. Elenga et al., 2000a), we apply non-metric multidimensional scaling (NMDS) to detect the adequate taxonomic level of pollen grain identification for reliable results on the corresponding afromontane vegetation. By comparing plant and pollen abundances, we assess biodiversity patterns as well as pollen and spore dispersal along the elevational gradient of Kilimanjaro.

Despite numerous studies on regional palaeoecology, few studies have characterized the palynological signatures of tropical montane ecosystems, hindering efforts to make ecological inference from palynological data. Despite its small sample size, the data set presented here represents the first statistical analysis of the pollen vegetation relationship along an elevational gradient in Africa, improving the interpretation of palynological records from the tropical East African mountains.

\section{Study area}

Kilimanjaro (Figure 1a) is located $300 \mathrm{~km}$ south of the equator in Tanzania on the border with Kenya between $2^{\circ} 45^{\prime}$ and $3^{\circ} 25^{\prime}$ south and $37^{\circ} 00^{\prime}$ and $37^{\circ} 43^{\prime}$ east. Kilimanjaro is an eroded relict of an ancient volcano with three peaks (Shira, Mawenzi and Kibo) rising from the savannah plains at $700 \mathrm{~m}$ elevation to a snow- and ice-clad summit of $5895 \mathrm{~m}$ a.s.l. (Downie et al., 1956) (Figure 1b). Kilimanjaro has a diameter from north-west to south-east of $90 \mathrm{~km}$

The investigated vegetation gradient extends from $1900 \mathrm{~m}$ a.s.l. in the submontane forest to the upper forest border at 3200 $\mathrm{m}$ a.s.l., and is located in close proximity to the river Weru-Weru (Figure 3c). 


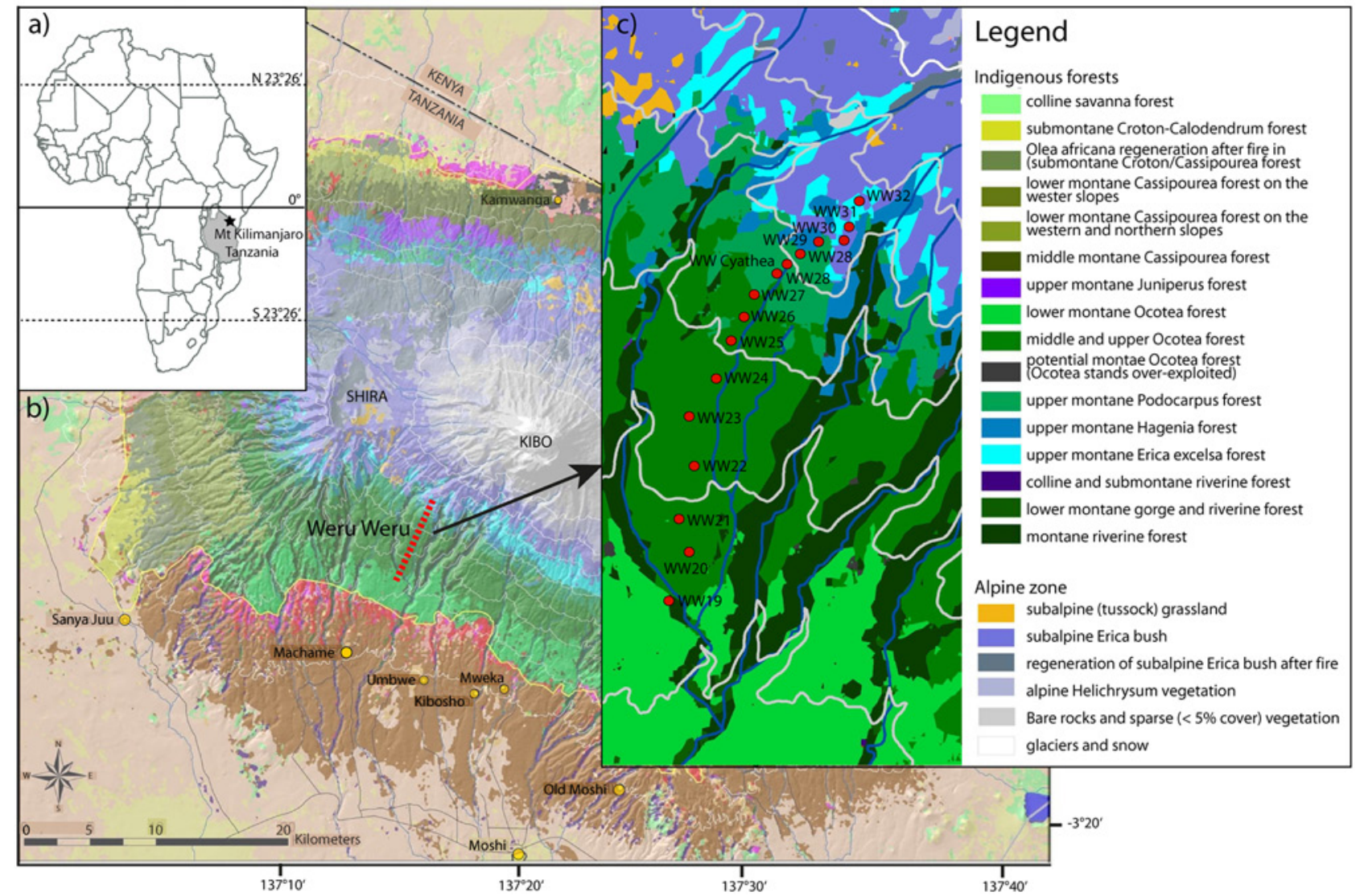

Figure I. (a) Map with location of Kilimanjaro, Tanzania: black solid line - equator; dotted lines - Tropic of Capricorn (south) and Tropic of Cancer (north). (b) Land use and vegetation map of Kilimanjaro: red dotted line indicates the pollen trap transect (for legend, see Figure Ic). (c) The Weru-Weru pollen trap transect from 1900 to 3200 m a.s.l. on the SE slope of Mt Kilimanjaro.

\section{Climate}

According to Köppen and Troll/Pfaffen (Müller, 1989) the Kilimanjaro area is characterized by a seasonally dry, tropical climate. Because of the influence of the position of the ITCZ and its proximity to the equator, Mt Kilimanjaro is characterized by a bimodal rainfall pattern and experiences four hydrological seasons per year: one short dry season in January and February, a long rainy season from March to May, a long dry season from June to September followed by a short rainy season in November and December.

The climate on Mt Kilimanjaro is further dependent on the elevation on the mountain and the exposition of the mountain side. Because of the prevalence of SE trade winds, the southern slope is generally wetter than the northern slope. Mean annual precipitation at the lowest pollen plot at $1950 \mathrm{~m}$ a.s.l. is about $2670 \mathrm{~mm} / \mathrm{yr}$ and increases to over $3050 \mathrm{~mm} / \mathrm{yr}$ between 2050 and $2350 \mathrm{~m}$ a.s.l. At higher elevations, precipitation decreases to $<1480 \mathrm{~mm} / \mathrm{yr}$ above $3250 \mathrm{~m}$ a.s.l. The mean annual temperature decreases from $14.3^{\circ} \mathrm{C}$ at $1950 \mathrm{~m}$ to $7.1^{\circ} \mathrm{C}$ at $3250 \mathrm{~m}$ a.s.l. with a lapse rate of $0.6^{\circ} \mathrm{C}$. Frost starts at $2950 \mathrm{~m}$ during cool nights in July and August (Hemp, 2006a). The predominance of the southeasterly trade wind at Kilimanjaro is modified by the mountain's topography causing strong downhill winds during the evening hours and weaker uphill winds during daytime (Hemp and Zimmermann, unpublished).

\section{Vegetation}

Covering about $5000 \mathrm{~km}^{2}$, Kilimanjaro has several distinct bioclimatic zones (Figure 1b) (Hemp, 2006a): A dry and hot colline savannah zone surrounds the mountain base between 700 and $1100 \mathrm{~m}$ a.s.l. Most of this area is used for crop production or as pastureland. Remnants of the former savannah vegetation with Acacia (Mimosaceae), Terminalia (Combretaceae), Grewia (Malvaceae) and Combretum (Combretaceae) woodlands are present mainly around Lake Chala in the eastern foothills and on the north-western side of the mountain. The submontane and lower montane forest (LMF) belt between 1000 and $1800 \mathrm{~m}$ a.s.l. have been converted to coffee-banana fields in the 'Chagga homegardens', a type of traditional agroforestry. Remnants of the former forests of this zone with Newtonia (Mimosaceae), Strombosia (Olacaceae) and Entandrophragma (Meliaceae) rarely occur outside of deep valleys and gorges.

The pollen trap transect (Figure 1c) starts in the LMF zone (defined after Hemp, 2006a), where Macaranga kilimandscharica (Euphorbiaceae), Agauria salicifolia (Ericaceae) and Ocotea usambarensis (Lauraceae) are the dominant tree species. This part of the transect is influenced by human activities such as fodder and wood collection and grazing by cattle.

Most vegetation study plots are located in the middle-montane forest (MMF) zone, which starts in the Weru-Weru area at $2200 \mathrm{~m}$ a.s.l. In this zone, humidity reaches its maximum value, indicated by the wealth of epiphytes and ferns, in particular filmy ferns and tree ferns. O. sambarensis (Lauraceae), Xymalos monospora (Monimiaceae), Ilex mitis (Aquifoliaceae) and Schefflera volkensii (Araliaceae) comprise the tree layer.

In the upper montane forest (UMF) zone above $2800 \mathrm{~m}$ a.s.l., Podocarpus latifolius (Podocarpaceae), Hagenia abyssinica (Rosaceae) and Prunus africana (Rosaceae) form the tree canopy. Additionally, monodominant stands of Erica excelsa (Ericaceae) play an important role in this zone, replacing Podocarpus and $H$. abyssinica forests after fire, forming the upper closed forest line on the southern slope of Kilimanjaro at $3250 \mathrm{~m}$ a.s.1. 
Table I. Location and forest type of the plots used for the vegetation survey and the installation of two pollen traps along the SE slope of Kilimanjaro. The number of traps installed in 2010 and recollected in $201 \mathrm{I}$ is given.

\begin{tabular}{|c|c|c|c|c|c|c|c|}
\hline \multirow[t]{2}{*}{ Plot } & \multirow[t]{2}{*}{ Altitude (m a.s.l.) } & \multicolumn{2}{|l|}{ Coordinates } & \multirow[t]{2}{*}{ No. of traps 2010} & \multirow[t]{2}{*}{ No. of traps 2011} & \multicolumn{2}{|c|}{ Vegetation zone } \\
\hline & & ${ }^{\circ} \mathrm{S}$ & ${ }^{\circ} \mathrm{E}$ & & & & \\
\hline WW 19 & 1952 & $03^{\circ} 09^{\prime} 34.6^{\prime \prime}$ & $37^{\circ} 15^{\prime} 38.4^{\prime \prime}$ & 2 & 2 & LMF & Ocotea-Agauria forest consisting of Ocotea \\
\hline WW 20 & 2030 & $03^{\circ} 09^{\prime} \mid 1.3^{\prime \prime}$ & $37^{\circ} 15^{\prime} 49.9^{\prime \prime}$ & 2 & I & LMF & usambarensis associated with Agauria salicifo- \\
\hline WW 21 & 2143 & $03^{\circ} 08^{\prime} 52.5^{\prime \prime}$ & $37^{\circ} 15^{\prime} 43 . I^{\prime \prime}$ & 2 & 1 & LMF & $\begin{array}{l}\text { lia, Syzygium guineense, Macaranga kilimand- } \\
\text { scharica and Polyscias fulva }\end{array}$ \\
\hline WW 22 & 2255 & $03^{\circ} 08^{\prime} 28.3^{\prime \prime}$ & $37^{\circ} 15^{\prime} 53.8^{\prime \prime}$ & 2 & 2 & MMF & \\
\hline WW 23 & 2378 & $03^{\circ} 08^{\prime} 06.8^{\prime \prime}$ & $37^{\circ} 15^{\prime} 51.9^{\prime \prime}$ & 2 & 2 & MMF & \\
\hline WW 24 & 2489 & $03^{\circ} 07^{\prime} 46.3^{\prime \prime}$ & $37^{\circ} 16^{\prime} 03.5^{\prime \prime}$ & 2 & 2 & MMF & Ocotea-Podocarbus forest, consisting of \\
\hline WW 25 & 2568 & $03^{\circ} 07^{\prime} 31.5^{\prime \prime}$ & $37^{\circ} 16^{\prime} 07.7^{\prime \prime}$ & 2 & 2 & MMF & O. usambarensis associated with Podocarpus \\
\hline WW 26 & 2681 & $03^{\circ} 07^{\prime} \mid 8.1$ & $37^{\circ} 16^{\prime} 17.7^{\prime \prime}$ & 2 & 2 & MMF & latifolius and the tree fern Cyathea manniana \\
\hline WW 27 & 2798 & $03^{\circ} 07^{\prime} 06.9^{\prime \prime}$ & $37^{\circ} 16^{\prime} 23.6^{\prime \prime}$ & 2 & 2 & MMF & \\
\hline WW C. & 2800 & $03^{\circ} 07^{\prime} 06.5^{\prime \prime}$ & $37^{\circ} 16^{\prime} 25.9^{\prime \prime}$ & 2 & 1 & MMF & \\
\hline WW 28 & 2879 & $03^{\circ} 06^{\prime} 58.5^{\prime \prime}$ & $37^{\circ} 16^{\prime} 30.9^{\prime \prime}$ & 2 & 1 & MMF & \\
\hline WW 29 & 3009 & $03^{\circ} 06^{\prime} 44.8^{\prime \prime}$ & $37^{\circ} 16^{\prime} 40.2^{\prime \prime}$ & 2 & 2 & UMF & Podocarpus-Ocotea forest with prevailing \\
\hline WW 30 & 3087 & $03^{\circ} 06^{\prime} 39.9^{\prime \prime}$ & $37^{\circ} 16^{\prime} 51.6^{\prime \prime}$ & 2 & 2 & UMF & P. latifolius \\
\hline WW 31 & 3176 & $03^{\circ} 06^{\prime} 33.6^{\prime \prime}$ & $37^{\circ} 17^{\prime} 06.7^{\prime \prime}$ & 2 & 2 & UMF & Hagenia-Podocarpus forest with P. latifolius, \\
\hline WW 32 & 3255 & $03^{\circ} 06^{\prime} 21.5^{\prime \prime}$ & $37^{\circ} 17^{\prime} 09.0^{\prime \prime}$ & 2 & 2 & UMF & Hagenia abyssinica and Prunus africana \\
\hline
\end{tabular}

LMF: lower montane forest, MMF: mid-montane forest, UMF: upper montane forest.

Above $3250 \mathrm{~m}$ a.s.l., the cloud forests are replaced by Erica heathlands. Erica trimera forest remnants at $4000 \mathrm{~m}$ a.s.l. indicate the upper potential natural forest line. Above this altitude, the Erica heathlands change into Helichrysum (Asteraceae) dwarf cushion vegetation that extends up to $4500 \mathrm{~m}$ a.s.l. The highest altitudinal region is very sparsely vegetated and the top of Kibo, the main summit, is covered with glaciers. For a more detailed description of these vegetation types, see Hemp (2001, 2006a, 2006c).

\section{Material and methods}

\section{Floristic inventories}

On the Weru-Weru transect, research plots at $100 \mathrm{~m}$ altitudinal intervals with vegetation records, soil profiles, rain gauges and data loggers for temperature and humidity were established in 2005. For our study, we used the 15 plots between 1950 and 3250 $\mathrm{m}$ a.s.l., since the forest below $1900 \mathrm{~m}$ a.s.l. is heavily disturbed and frequented by people collecting firewood and fodder. The plots measured $50 \mathrm{~m} \times 50 \mathrm{~m}$. The plot size was chosen with respect to the minimum area calculated with the nested plot method (as suggested by Mueller-Dombois and Ellenberg, 1974). Three plots were located within the LMF (1900-2100 m a.s.1.), eight in the MMF (2200-2800 m a.s.l., including one additional plot at the upper distribution border of Cyathea manniana) and four in the UMF (2900-3200 m a.s.1.). Plant taxa abundances were estimated using the Braun-Blanquet (1964) cover-abundance scale for vegetation analysis. Estimating the coverage and abundance of plant species is one of the methods of vegetation description.

\section{Modern pollen-rain sampling and laboratory methods}

In total, 30 pollen traps were installed along the elevational transect used for the floristic inventories (see above) in February 2010. Two traps were installed at every vegetation plot. The same pollen trap type was used as suggested by Behling et al. (2001) and Niemann et al. (2010) using 50-mL test tubes with $3 \mathrm{~mL}$ glycerine and synthetic cotton and a net as cover installed $10 \mathrm{~cm}$ above the ground. In all, 26 pollen traps were recollected in February 2011 (Table 1)
Pollen was extracted from the 'Behling traps' by centrifuging and sieving the samples. Afterwards, acetolysis was carried out on the samples to dissolve cellulose material and to stain the pollen residues. The pollen residue obtained was kept in distilled water until mounted into glycerol jelly for pollen analysis. For each sample, we counted at least 300 pollen grains. Fern spores were also counted and expressed as percentages of the pollen sum (but not included in it). Pollen and spore identification was based on the reference collection of about 2000 slides of the Department of Palynology and Climate Dynamics, Göttingen University, the African Pollen Database (Lézine, 2001) and relevant literature (Bonnefille, 1971).

A pollen percentage diagram was compiled with the software C2 Version 1.7.2 (Juggins, 2011), illustrating the most abundant and ecologically important taxa (Figure 3). Pollen taxa were assigned to forest zones in accordance with Hemp (2006a).

\section{Multivariate data analysis}

NMDS was applied to investigate the similarity between pollen traps within one plot, the representivity of the surrounding vegetation by pollen-rain composition and the taxa level needed to be able to differentiate between forest zones based on the modern pollen-rain assemblage.

NMDS is a data reduction technique that projects multivariate data along latent axes in distance measure-based space and preserves the underlying dissimilarity structure between points (McCune et al., 2002). In this way, highly multivariate data can be represented in a lower dimensional space while preserving the data structure. In contrast to 'conventional' ordination methods such as canonical correlation analysis, NMDS effectively combines the shared variance of implicit causal factors along the axes rather than defining the structural attributes a priori (McCune et al., 2002).

The NMDS was performed using the meta-MDS function contained in the vegan package for R (Oksanen et al., 2013). Pollen proportions were calculated based on the total of the pollen subset selected for analysis: 126 identified pollen types. The species data were square root transformed as suggested for community data with skewed abundance distribution and many zero values. The NMDS distance matrix was calculated using the Bray-Curtis distance between study sites based on the square-root-transformed 
pollen data. Constrained ordination procedures were not used because long-distance pollen transport and narrow elevation (and thus temperature and precipitation) gradients are likely to result in violations of the underlying assumptions of these methods. Among unconstrained ordination procedures, principal component analysis is a poor choice as it assumes linear relationships between variables and short ecological gradients (Kent, 2006), requiring multivariate normality (McCune et al., 2002). The pollen and climate data in this study do not meet these assumptions, which limits our ability to apply the technique of Anderson and Willis (2003) who recognize that canonical analysis of principal coordinates cannot replace NMDS for certain applications. Because NMDS evaluates data structure using dissimilarity measures, it allows estimates to be made based on dissimilarity and directionality. Furthermore, as points are placed into space using information from the entire data set rather than one or several proximate points, problems associated with spatial autocorrelation (Telford and Birks, 2005) are mitigated. The dimensionality of the final ordination was determined when the Kruskal stress of the ordination declined successively by increasing dimensions (McCune et al., 2002). The maximum number of random starts in search of stable solution was set to 100 .

For the investigation of the influence of the taxonomic level on the possibility to derive certain forest zones from the pollenrain, the pollen types were assigned to their plant families (67 identified families in total).

\section{Representativeness of plant families in the modern pollen-rain}

Some pollen types are difficult to determine at genus level but can easily be assigned to a plant family. Hence, for the data analysis, the identified pollen types were pooled on family level. To investigate how the vegetation is represented in the pollen traps, we compare the percentages of plant families present in the vegetation cover and in the pollen-rain. This was done separately for every forest zone (LMF, MMF and UMF) for all plant families present in both data sets. To enable calibration according to the relationship between the percentage of the family within the pollen trap and the surrounding vegetation, we generate a transfer factor $(\mathrm{TF}=(\%$ taxon in vegetation $) /(\%$ taxon in pollen-rain $))$. This factor, which can also be applied to fossil pollen data (Marchant and Taylor, 2000), compensates for differences in representativeness of pollen. The comparison of the transfer factors of the different forest zones also allows further ecological conclusions on pollen production and dispersal.

\section{Assessing biodiversity}

Plant diversity was assessed by comparing the number of plant families in the pollen traps and in the corresponding vegetation plot. This comparison was also done on generic and specific level of plant taxa and pollen types.

\section{Pollen and spore dispersal}

For assessing pollen and spore dispersal, we made a comparison between the abundance of Cyperaceae and Cyathea in the vegetation and in the modern pollen-rain. Those two taxa are very abundant and most likely to capture the wind pattern in their pollen/ spore distribution. Cyperaceae release their pollen during day and night, while the sporangia of Cyathea are only open only during the day when climate conditions are dry. Both taxa have defined ecological limits of their distribution within the studied altitudinal transect which facilitates the detection of pollen/spore shifts. In each case, the vegetation cover and the pollen/spore data were plotted against the altitude. For the vegetation cover, we applied a moving average to the data set (window size of 3 ) to smooth out short-term fluctuations caused by the transformation of the BraunBlanquet (1964) scale into percentage values, and to highlight long-term trends.

\section{Results}

\section{Multivariate data analysis}

The NMDS of the modern pollen-rain data (Figure 2) provides information on the differences between individual pollen traps and between different vegetation plots derived from the modern pollen-rain data based on identified pollen types and at family level. The degree of correspondence between the distances among points implied by NMDS diagram, and the data matrix input is measured (inversely) by a stress function called Kruskal stress. When the NMDS diagram perfectly reproduces the input data, the stress value is zero. For all three ordinations, the Kruskal stress was reduced to values below 0.1 when using three dimensions in the NMDS

In Figure 2a, the NMDS of the individual pollen traps based on the pollen types is shown (Kruskal stress: 0.085). Pollen traps of the same plot are clustered. Furthermore, samples of the pollen traps ranging from 1900 to $2100 \mathrm{~m}$ a.s.1., which correspond to the LMF (Hemp, 2006a), are grouped as well as samples from 2200 to $2400 \mathrm{~m}$ a.s.l. (lower mid-montane forest, lMMF), 2500 to 2800 $\mathrm{m}$ a.s.l. (upper mid-montane forest, uMMF) and 2900 to $3200 \mathrm{~m}$ a.s.l. (UMF).

In Figure 2b, the NMDS of the pollen traps - pooled per plot - based on the pollen type families is shown (Kruskal stress: 0.048). The pattern of the sample distribution is similar to the one revealed by the NMDS based on the pollen types (Figure 2a). Samples of 1900-2100 m a.s.l. (LMF) are most strongly correlated with Euphorbiaceae, Lauraceae, Acanthaceae and Apocynaceae. Pollen samples from plots from 2200 to $2800 \mathrm{~m}$ a.s.l. are clustered in the upper part of the ordination space. While samples from 2200 to $2400 \mathrm{~m}$ a.s.l. are correlated with Aquifoliaceae, Araliaceae, Moraceae, Piperaceae, Ebenaceae and Dracaenaceae, samples from 2500 to $2800 \mathrm{~m}$ a.s.1. are characterized by Poaceae, Oleaceae, Rubiaceae and Amaranthaceae. Pollen trap samples taken at 2900-3200 $\mathrm{m}$ a.s.l. are positioned in the lower right of the diagram and are clustered with Myricaceae, Ericaceae and Rosaceae.

Figure 2c shows the NMDS of the modern pollen-rain samples per plot based on the pollen grain (morphological) types (Kruskal stress: 0.048). The samples of 1900-2100 m a.s.l. are clustered in the lower part of the diagram and are most strongly correlated with the abundance of Macaranga (Euphorbiaceae), Acanthaceae, Ocotea (Lauraceae) and Tabernaemontana (Apocynaceae).

Samples of 2200-2400 $\mathrm{m}$ a.s.l. are located in the lower half of the ordination diagram and are correlated with the abundance of Piper (Piperaceae), Rubiaceae (Psychotria, Pavetta) and Moraceae/Urticaceae. Samples from 2500 to $2800 \mathrm{~m}$ a.s.l. reflect mostly Podocarpus (Podocarpaceae), Schefflera (Araliaceae), Olea (Oleaceae) and Myrica (Myricaceae).

The pollen trap samples from 2900 to $3200 \mathrm{~m}$ a.s.1. are positioned in the upper left quadrant of the diagram. They are correlated with the modern pollen-rain types of Hagenia (Rosaceae), Erica (Ericaceae), Artemisia (Asteraceae), Viola (Violaceae) and Hypericum (Hypericaceae). Two subgroups are noticeable. Samples from 2900 and $3200 \mathrm{~m}$ a.s.l. are clustered and correlated with Erica and Hypericum, whereas the samples from 3000 and 3100 m a.s.l. are correlated stronger with Hagenia.

\section{Representativeness}

The pollen percentage diagram (Figure 3) of modern pollen-rain shows sums of forest zones, LMF, MMF and UMF, and most 

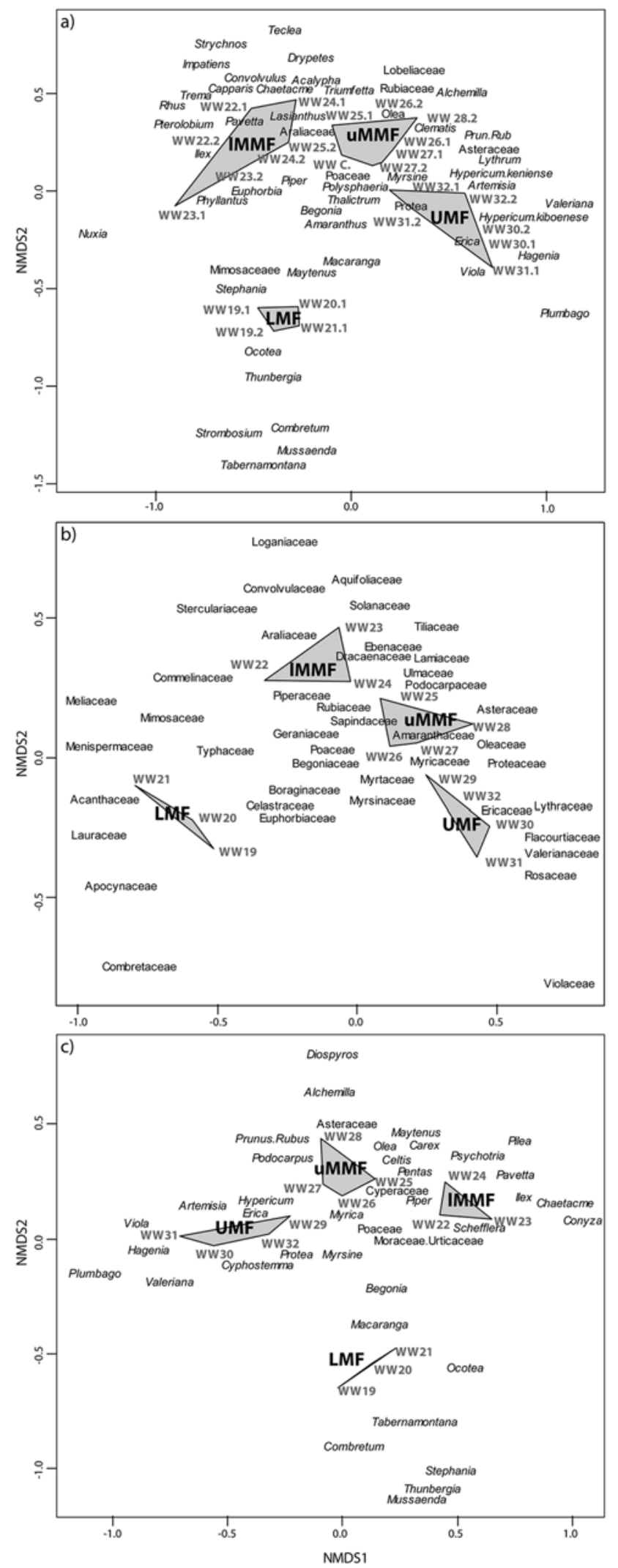

Figure 2. Non-metric multidimensional scaling (NMDS) diagram. The NMDS finds the relationship between the dissimilarities in the item-item matrix and the Euclidean distances between items, and the location of each item in the low-dimensional space. The polygons represent the different forest zones as classified by Hemp (2006a): LMF - lower montane forest; IMMF - lower mid-montane forest; UMMF - upper mid-montane forest; UMF - upper montane forest. The pollen traps in (a) and the plots in (b) and (c) are labelled with WW and the corresponding elevation (e.g.WW27 means plot at $2700 \mathrm{~m}$ a.s.l.). (a) NMDS of the individual pollen traps based on the pollen types, (b) NMDS of the pollen trap plots based on the pollen families and (c) NMDS of the pollen trap plots based on the individual pollen types.

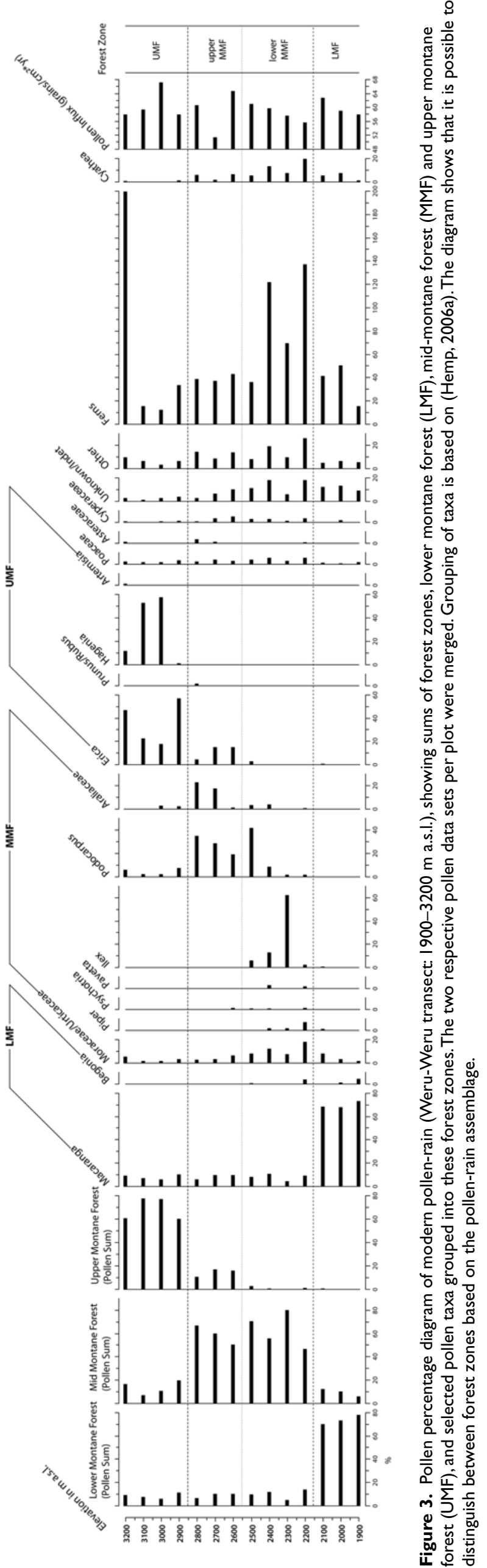



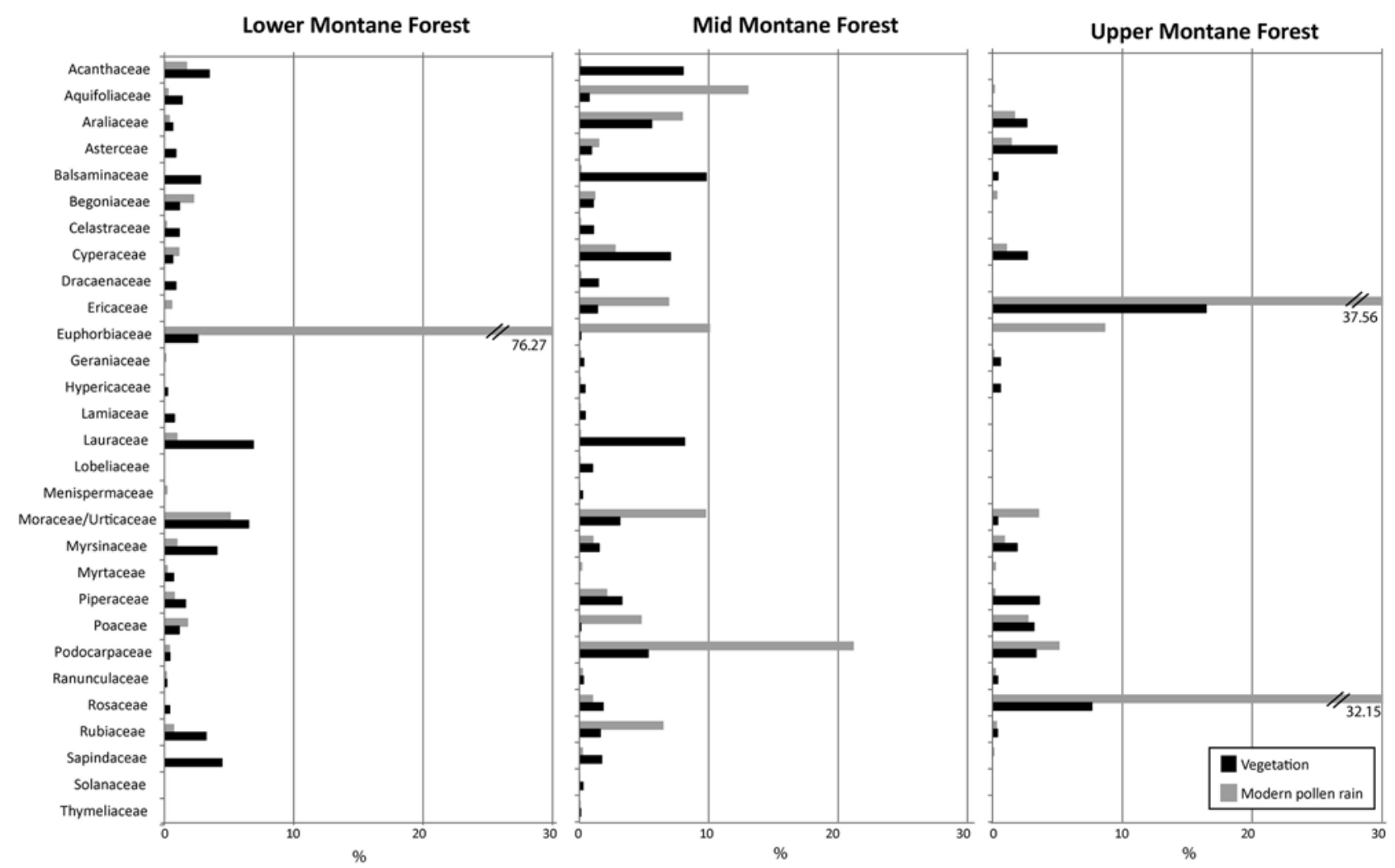

Figure 4. Summary histogram comparing percentage data on family level of the modern pollen-rain and plant taxa in vegetation plots for the different montane forest zones. "//' indicates a scale break which is used to display large values on the $\mathrm{x}$-axis.

abundant pollen and ecologically distinctive taxa grouped into these forest zones. Taxa associated with the LMF in the modern vegetation such as Macaranga and Begonia are major elements of the modern pollen-rain between 1900 and $2200 \mathrm{~m}$ a.s.l. Major pollen taxa of the MMF (e.g. Podocarpus, Ilex, Araliaceae) and of the UMF (e.g. Erica, Artemisia, Alchemilla, Hypericum) are also abundant in the corresponding forest zones of the vegetation. Major pollen taxa of the MMF (e.g. Podocarpus, Ilex, Araliaceae) and of the UMF (e.g. Erica, Artemisia, Alchemilla, Hypericum) are also abundant in the corresponding forest zones of the vegetation. Taxa associated with the MMF such as Piper, Psychotria and Pavetta show a pollen displacement into the lowermost MMF. Additionally, taxa from the UMF such as Alchemilla, Prunus/Rubus and Hypericum also show an elevational displacement into the uppermost MMF.

The representativeness of plant families in the modern pollenrain in comparison with their abundance in the surrounding vegetation is shown in Figure 4 and summarized as transfer factors (TF) in Table 2. A TF close to 1 means that the percentage abundance of a plant family in the pollen record is about equal to the one in the vegetation. TF values $<1$ indicate over-representation in the pollen record, and TF values $>1$ mean underrepresentation. In the LMF, the percentage of Euphorbiaceae (represented only by Macaranga) is much higher in the pollen record $(76 \%)$ than in the vegetation $(3 \%)$, resulting in a low TF $(0.03)$. In contrast, the pollen percentages of Lauraceae (1\%) and Rubiaceae (1\%) are lower than in the present-day vegetation $(7 \%$ and $3 \%$, respectively) resulting in high TFs ( 7 and 5, respectively). In the MMF, the pollen record shows high percentages for Aquifoliaceae (13\%), Euphorbiaceae (mainly Macaranga) (10\%), Moraceae/ Urticaceae (10\%) and Podocarpaceae (21\%), whereas for Cyperaceae $(3 \%)$, Balsaminaceae $(<1 \%)$ and Lauraceae $(<1 \%)$, the pollen percentages are clearly lower than the families' abundances in the vegetation. While pollen percentages in the UMF are high for Ericaceae (38\%), Rosaceae (32\%), Euphorbiaceae (9\%), Moraceae/Urticaceae $(4 \%)$ and Podocarpaceae $(5 \%)$, they are low for
Cyperaceae (1\%), Piperaceae $(<1 \%)$ and Poaceae $(3 \%)$ in comparison with their abundance in the surrounding vegetation.

\section{Biodiversity}

The plant diversity shows a decreasing trend with increasing elevation in the vegetation. This is also found in the modern pollenrain (Figure 5). In the vegetation, the highest number of species (85) and families (51) is recorded at $1900 \mathrm{~m}$ a.s.l. The number of species reaches another maximum at $2700 \mathrm{~m}$ a.s.1. (69 species) and then decreases to 31 species in 23 families at $3200 \mathrm{~m}$ a.s.1. The diversity found in the modern pollen-rain has its minimum at $2000 \mathrm{~m}$ a.s.1., with only 19 pollen types in 16 plant families, it reaches 81 pollen types in 40 families at $2200 \mathrm{~m}$ a.s.l. and then decreases again to 29 pollen types in 23 plant families at $3200 \mathrm{~m}$ a.s.l. The pollen diversity is generally lower than the diversity in the vegetation, but they approximate with increasing elevation. At $2200 \mathrm{~m}$ and at $3100 \mathrm{~m}$ a.s.l., the number of plant families recorded in the modern pollen-rain exceeds slightly the number of families in the vegetation.

\section{Pollen and spore dispersal}

Figure 6a depicts the abundance of Cyathea spores in the pollen traps and the vegetation cover along the altitudinal gradient. While in the vegetation Cyathea can only be found up to about $2800 \mathrm{~m}$ a.s.1., it still occurs in the spore signal at $3200 \mathrm{~m}$ a.s.l. (and potentially even higher). The pattern of abundance along the altitudinal gradient shows a phase shift between vegetation and pollen record. The occurrence of Cyathea in the spore record is shifted by about $100 \mathrm{~m}$ uphill compared with the occurrence in the vegetation. While Cyathea comprises around $60 \%$ of the modern-day vegetation cover at $1980 \mathrm{~m}$ a.s.1., this maximum can only be observed at about $2200 \mathrm{~m}$ a.s.l. in the spore record.

A comparison of the percentage of Cyperaceae pollen in the record along the elevational gradient with the abundance of 
Table 2. Information on representativeness given for all plant families that were recorded at least once in the pollen traps. The transfer factors (TFs) are shown when the family is present within the pollen record and the vegetation survey.

\begin{tabular}{|c|c|c|c|}
\hline & LMF & MMF & UMF \\
\hline Acanthaceae & 2.03 & 62.79 & \\
\hline Amaranthaceae & 1.88 & $x$ & $x$ \\
\hline Aquifoliaceae & 4.60 & 0.06 & $x$ \\
\hline Araliaceae & 1.73 & 0.70 & 1.55 \\
\hline Asteraceae & st & 0.62 & 3.44 \\
\hline Balsaminaceae & st & 75.31 & st \\
\hline Begoniaceae & 0.51 & 0.90 & $x$ \\
\hline Brassicaceae & & 12.17 & st \\
\hline Celastraceae & 7.07 & 12.70 & \\
\hline Commelinaceae & 3.74 & $x$ & \\
\hline Cyperaceae & 0.58 & 2.55 & 2.50 \\
\hline Dracaenaceae & st & 14.23 & \\
\hline Ericaceae & $x$ & 0.20 & 0.44 \\
\hline Euphorbiaceae & 0.03 & 0.01 & $x$ \\
\hline Fabaceae & st & 4.31 & $x$ \\
\hline Flacourtiaceae & st & $x$ & $x$ \\
\hline Geraniaceae & $x$ & 3.45 & 5.53 \\
\hline Hypericaceae & st & 6.54 & st \\
\hline Lamiaceae & st & 6.82 & \\
\hline Lauraceae & 7.16 & 104.05 & \\
\hline Lobeliaceae & & 15.82 & \\
\hline $\begin{array}{l}\text { Menisperma- } \\
\text { ceae }\end{array}$ & $x$ & 9.66 & \\
\hline $\begin{array}{l}\text { Moraceae/Urti- } \\
\text { caceae }\end{array}$ & 1.28 & 0.32 & 0.11 \\
\hline Musaceae & st & $x$ & \\
\hline Myricaceae & 0.38 & 0.00 & $x$ \\
\hline Myrsinaceae & 4.21 & 1.45 & 2.08 \\
\hline Myrtaceae & 3.30 & $x$ & $x$ \\
\hline Piperaceae & 2.15 & 1.56 & 19.74 \\
\hline Plantaginaceae & st & st & $x$ \\
\hline Poaceae & 0.64 & 0.02 & 1.17 \\
\hline Podocarpaceae & 1.13 & 0.25 & 0.65 \\
\hline Polygonaceae & & 0.42 & st \\
\hline Ranunculaceae & 1.17 & 1.41 & 1.79 \\
\hline Rosaceae & st & 1.79 & 0.24 \\
\hline Rubiaceae & 4.58 & 0.25 & 1.25 \\
\hline Sapindaceae & st & 7.49 & $x$ \\
\hline Solanaceae & & 11.06 & \\
\hline Sterculariaceae & st & $x$ & \\
\hline Thymeleaceae & & 1.77 & \\
\hline Violaceae & & st & 7.54 \\
\hline Vitaceae & st & & $x$ \\
\hline
\end{tabular}

LMF: lower montane forest, MMF: mid-montane forest, UMF: upper montane forest; st: recorded in vegetation but not in the modern pollen-rain (silent taxon); $x$ : not in vegetation but in pollen record; TF < $\mathrm{I}$ : over-represented in pollen record; TF > I: underrepresented in pollen record;TF $\sim \mathrm{I}:$ equivalently represented in pollen record; Empty cell: taxa recorded neither in vegetation nor in pollen-rain;

Cyperaceae in the surrounding vegetation cover (Figure 6b) shows different distribution patterns. Cyperaceae contribute between $0.5 \%$ and $3 \%$ of the total modern pollen-rain up to an elevation of $2400 \mathrm{~m}$ a.s.l. At $2600 \mathrm{~m}$ a.s.l., they reach a maximum of $4 \%$, followed by a strong decrease of Cyperaceae pollen to less than $2 \%$ at higher elevations. In the present-day vegetation, Cyperaceae are most abundant (38\% vegetation cover) around $2800 \mathrm{~m}$ a.s.l. Between $2300 \mathrm{~m}$ and $2700 \mathrm{~m}$ a.s.l., the abundance fluctuates between $5 \%$ and $16 \%$. At lower elevations, Cyperaceae only represent $1-2 \%$ of the vegetation.

\section{Interpretation and discussion}

The NMDS of the individual pollen traps (Figure 2a) reveals only minor differences of modern pollen-rain assemblages between the pollen traps within one plot. Consequently, the individual pollen traps are similarly representative of the surrounding vegetation.

Some differences between the pollen traps, for example, at $3100 \mathrm{~m}$ a.s.l., are caused by the abundance of $H$. abyssinica. $H$. abyssinica is a strong pollen producer, but because of the relatively large pollen grains, the pollen dispersal over larger distances is rather low (Jackson and Lyford, 1999). Hence, the dominance of $H$. abyssinica pollen in the modern pollen-rain is likely to be a local signal because of the presence of single $H$. abyssinica trees. The close similarity of taxa composition within pollen traps of one plot is an essential prerequisite for any further investigations.

The NMDS also shows that the pollen traps are not only representative for the vegetation of the direct surroundings but also for the corresponding vegetation zone described by Hemp (2006a) along the elevational gradient of Kilimanjaro (see also Figure 3). The resemblance of samples of the same forest zone (LMF, MMF and UMF) is much higher than in-between the forest zones.

In the LMF, M. kilimandscharica (Euphorbiaceae), a wind-pollinated species, is very abundant in the vegetation and the major component of the pollen-rain record. The over-representation of M. kilimandscharica in the LMF is also likely because of the species' ability to produce vast amount of pollen grains.

Abundant Cyperaceae, Rubiaceae, Moraceae, Urticaceae, Piperaceae, Araliaceae, Podocarpus and Ilex generally characterize the vegetation of the MMF. However, two forest subtypes, as described by Hemp (2006a), can be detected in the modern pollen-rain: the lower MMF (2200-2400 m a.s.l.) and the upper MMF (2500-2800 m a.s.1.). The lower MMF (2200-2400 m a.s.1.) is characterized by abundant Schefflera (Araliaceae), Begonia (Begoniaceae), Ilex (Aquifoliaceae) and several Rubiaceae taxa (Psychotria, Pavetta, Pauridiantha). The relative strong abundance of Podocarpus and Urticaceae (Pilea) in the pollenrain represents the vegetation cover of the upper MMF (2500 $2800 \mathrm{~m}$ a.s.1.). Podocarpus is most abundant at $2700-2800 \mathrm{~m}$ a.s.1., which is also reflected in the modern pollen-rain. In addition, Prunus and Rubus (both Rosaceae) can be used as indicator taxa for this upper MMF in the pollen record.

The UMF above $2900 \mathrm{~m}$ a.s.l. is dominated by H. abyssinica (Rosaceae) and Erica (Ericaceae) as a result of forest fires during the past. The abundance of Hypericum (Hypericaceae), Valeriana (Valerianaceae) and Violaceae in the pollen-rain also indicates a more open forest structure. Artemisia (Asteraceae), Geranium (Geraniaceae), Protea (Proteaceae) and Myrsine (Myrsinaceae) are typical taxa of the Erica zone, which replaces the UMF above $3200 \mathrm{~m}$ a.s.l.

The forest zones observed in the present-day vegetation are reflected well in the modern pollen-rain composition, independent on which taxonomic level is analysed. More specifically, our results indicate that the modern pollen-rain composition using only plant families is already very decisive when aiming at distinguishing between LMF, lower and upper MMF and UMF along the elevational gradient. Therefore, our results support the suggestion by Minckley and Whitlock (2000) that it is not always necessary to use the full suite of pollen taxa present if the goal is to reconstruct vegetation at the level of vegetation type or zone.

Even though the dominant plant families in the pollen-rain are not in all cases also the abundant ones in the vegetation, their occurrence facilitates the detection of forest zones, as is also suggested by Niemann et al. (2010). The more detailed ecological interpretation and floristic characterization within the forest zones can then be continued based on key taxa. Nevertheless, some aspects have to be taken into account. First, plant families consist 


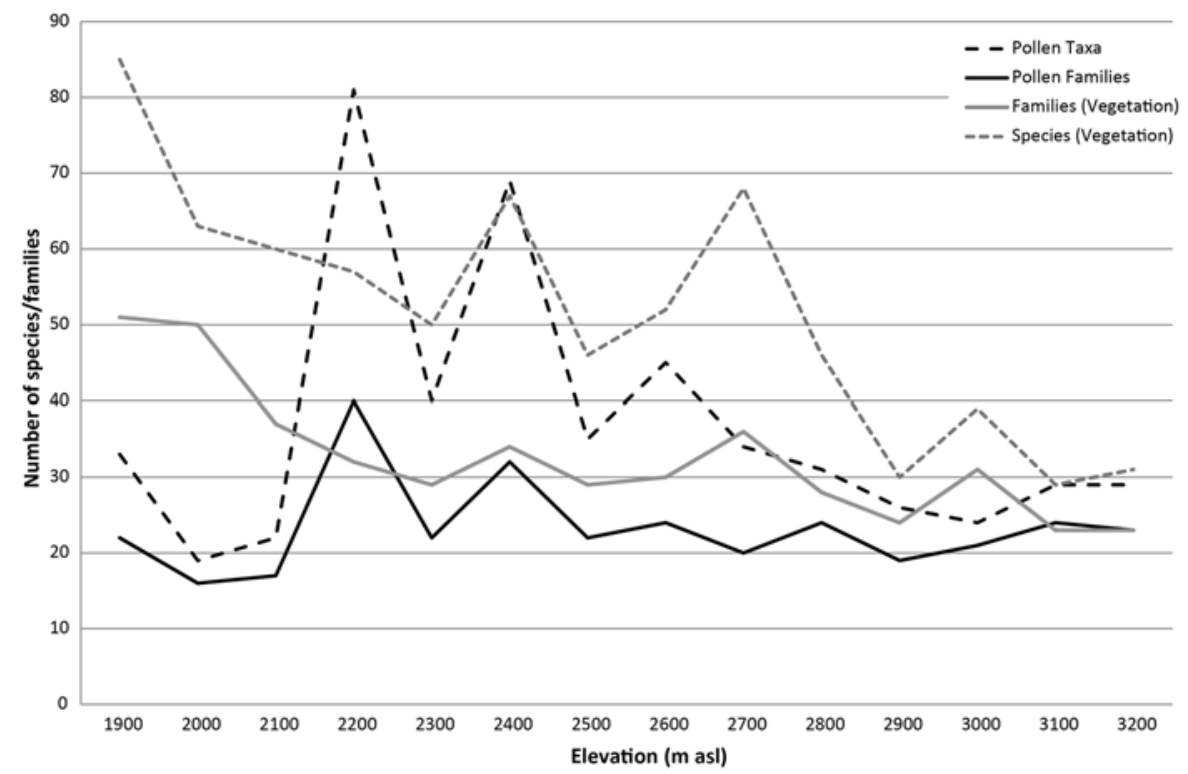

Figure 5. Number of plant species and pollen taxa plotted along the elevational gradient. Additionally, the number of families derived from the species and the pollen taxa are given.

in most cases of many species, which can have different ecological demands. Second, the pollen productivity and dispersal vary between species. As many tropical trees are animal pollinated (Bawa and Hadley, 1990), the relationship between pollen deposition and plant distribution is not linear.

The representativeness of a plant family adds important qualitative information for the interpretation. Our results show that the representativeness of a plant family is not the same in all the forest zones (each spanning an elevational difference of 300-500 m). However, Ericaceae and Euphorbiaceae (mainly Macaranga) are strongly over-represented in the pollen record of the forest zones. Both Ericaceae and the genus Macaranga are strong pollen producers and have comparably small pollen grains, which would lead to such a representativeness pattern. Their pollen grains also seem to be subject to long-distance dispersal since they are recorded in plots where they do not appear in the vegetation.

Taxa that have a high TF value and that occur as silent taxa (present in the flora but unrecorded in pollen-rain) such as Hypericaceae or Balsaminaceae indicate weak pollen production and insect pollination. Taxa which appear with a low TF in one forest zone and are not in vegetation but in pollen record (' $x$ ' in Table 2) in other zones suggest that they are strong pollen producers (e.g. Erica) or their pollen is wind transported (e.g. Myrica).

The over-representativeness of Ericaceae, Rosaceae (H. abyssinica), Euphorbiaceae (M. kilimandscharica), Podocarpus and Araliaceae supports the finding of Marchant and Taylor (2000) who show that these taxa are probably significantly less important components of the surrounding vegetation than indicated by the modern pollen-rain.

The elevational gradient of plant diversity shows a humpshaped elevational species richness pattern which is known from other elevational gradient studies on mountain systems, and it is assumed to be related to the overlap of distributional ranges and the absence of extreme life conditions (Becker et al., 2007). This range-overlap effect is known to be particularly pronounced in the transition zone from montane forests to alpine vegetation (Kessler, 2001; Körner, 2003). On Kilimanjaro, this was shown for overall vascular plant diversity and in particular for Pteridophytes in relation to habitat variety, which is a major controlling factor of species richness (Hemp, 2002). At the upper forest border, fires start to become important on Kilimanjaro, creating a mosaic of different fire-induced successional stages of forest, shrub and tussock grassland stands (Hemp and Beck, 2001). Here, high community (beta) diversity in the fire-influenced areas of the upper montane zone leads to a higher species (alpha) diversity as compared with the closed undisturbed forest at lower altitudes and the monotonous Erica bush at higher altitudes (Hemp, 2001, 2006b).

We observe a similar overlap effect in the pollen diversity pattern. Highest values for pollen diversity are found in forest-type transition zones where the taxa composition in the vegetation changes substantially. This is the case at $2100-2200 \mathrm{~m}$ a.s.l., the transition from LMF to MMF, and at 3100-3200 m a.s.l. where the montane forest is replaced by ericaceous and alpine vegetation.

The diversity trend captured in the modern pollen-rain reflects the plant diversity in the vegetation. Substantial differences in numbers of taxa are probably because of the high proportion of insect-pollinated plants in the tropics (Bawa, 1983), which are mostly not or only rarely recorded in the pollen-rain. Towards more open vegetation in the UMF and the Erica zone, the pollen diversity reflects the plant diversity much better. It seems that our results in tropical montane vegetation confirm the finding by Tauber (1967) who proposed that under closed canopy cover, the pollen assemblage is a more local signal, whereas in more open areas, a wider range is recorded. Consequently, the pollen diversity reflects the plant diversity pattern independent of the investigated taxa level but that it can only be interpreted in consideration of the specific vegetation type and surrounding flora. Unlike the findings by Elenga et al. (2000a), our results from Kilimanjaro propose a good reflection of diversity patterns in the modern pollen-rain.

Cyperaceae recorded in the pollen-rain is only to some extent correlated to the present-day vegetation distribution of Cyperaceae. The results suggest a downwards shift of the distribution pattern reflected in the pollen-rain. The maxima of the Cyperaceae abundance in the vegetation at $2800 \mathrm{~m}$ and between 2400 and $2600 \mathrm{~m}$ a.s.l. are recorded about $500-600 \mathrm{~m}$ lower in the pollen-rain. Cyperaceae, which are wind pollinated, have rather light and non-sticky pollen so that they can be transported by air currents. Hence, this downslope shift of Cyperaceae pollen signal is likely caused by strong downward winds, which prevail on the slopes of Kilimanjaro during evening time. In contrast, the spores of Cyathea are large (between 80 and $120 \mu \mathrm{m}$ ) and not easily 

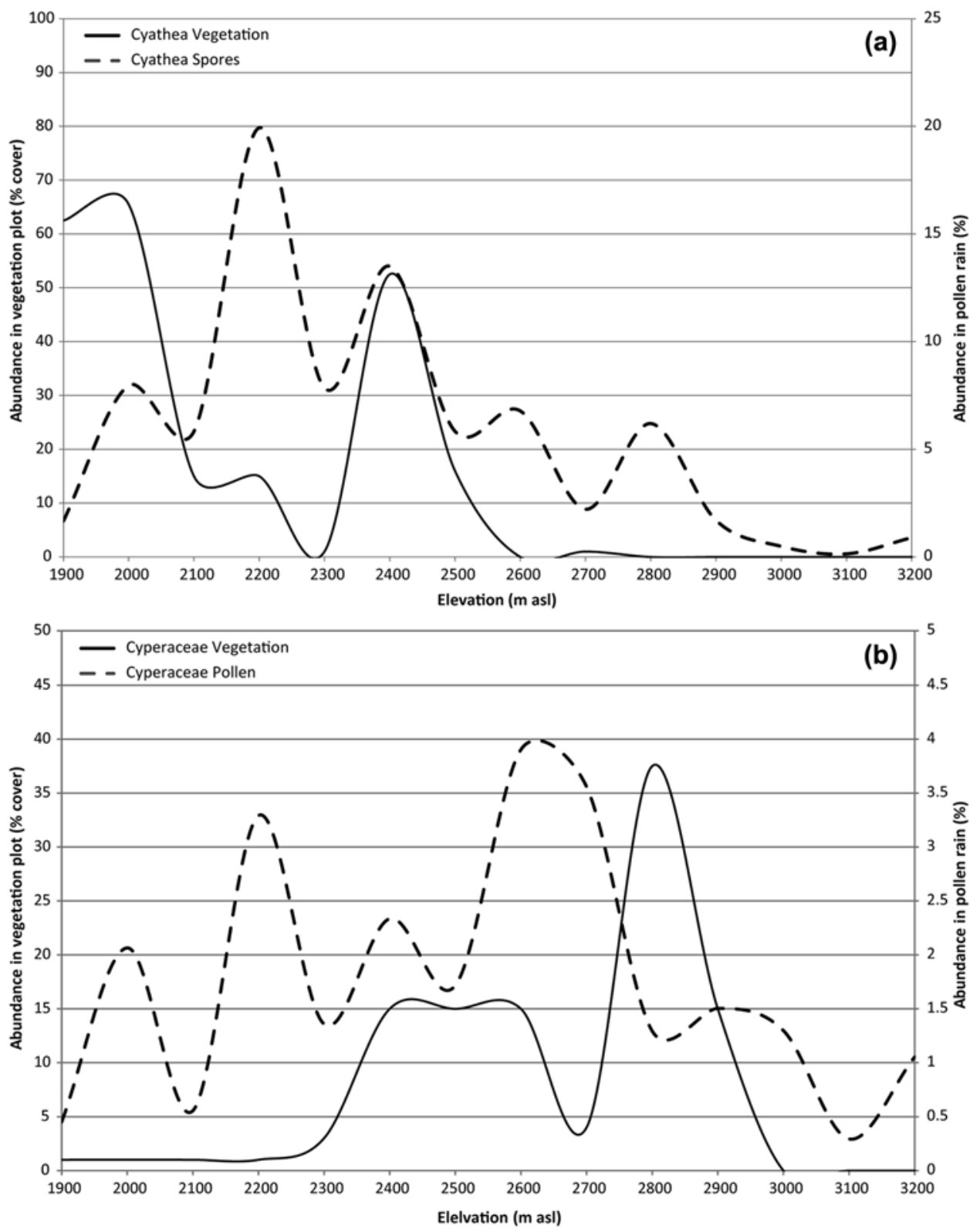

Figure 6. Comparison between the plant abundance in the vegetation and the percentage in the pollen record: (a) Cyathea and (b) Cyperaceae.

transported over long distances. The spore record of Cyathea reflects an average shift by only about $200 \mathrm{~m}$ elevation; however, in an upward direction. While the highest occurrence in the vegetation is at $2850 \mathrm{~m}$ a.s.l., Cyathea spores can still be found in the pollen traps at $3200 \mathrm{~m}$ a.s.l. This could be explained by the characteristic of ferns to release their spores under dry environmental conditions, which prevail during daytime, which is also the time of upward winds along the slopes of Kilimanjaro. Hence, our results suggest a positive correlation not only between the pollen/ spore drift and wind direction but also between drift distance and the wind force.

Our results show that even in closed canopy sites, there is a representation of non-local $(>100 \mathrm{~m})$ sources. This agrees with the findings by Sugita (1993) and Jackson and Wong (1994). However, our results show that in closed canopy sites, non-local taxa with low pollen production are also represented.

In the forests of Panama and Costa Rica, wind-dependent pollen transport was also observed for sparsely vegetated montane zones (Bush, 2000). In contrast to these findings, we do not observe a masking effect by local vegetation in the downslope transport into more dense vegetation.

\section{Conclusion}

Our modern pollen-rain study along the elevational gradient on Kilimanjaro reveals that it is crucial to establish a modern pollenrain - vegetation relationship for the calibration and interpretation of a fossil pollen record from mountain sites. It is possible to analyse the pollen-rain on plant family level in order to derive the forest zone of the surrounding vegetation and with this assess the climatic conditions, which is important for the interpretation of palaeo-records. The occurrence of plant families along the altitudinal gradient is differently represented in the modern pollen depending on various reproduction factors. This can be quantified as a transfer factor, which will be applied to calibrate palaeopollen data in future studies. The diversity trend captured in the modern pollen-rain reflects the plant diversity in the vegetation, but we observed differences in the taxa richness. The pollen and spore dispersal seems to be strongly influenced by the regional wind patterns. This needs to be considered when deriving past distribution ranges from pollen records.

Our results facilitate the confident use of fossil pollen data to reconstruct, more precisely, potential vegetation and its dynamics 
in East African montane forests, and to refine climate reconstructions based on transfer functions.

\section{Acknowledgements}

The authors would like to thank Martin Zweigert for his assistance during field and lab work and the Commission for Science and Technology (COSTECH), Tanzania, for permitting our research.

\section{Funding}

This work was funded by the German Research Foundation (DFG, BE 2116/15-1) and the University of Bayreuth. During the fieldwork, we made use of the infrastructure of the DFG Research Group KiLi.

\section{References}

Anderson MJ and Willis TJ (2003) Canonical analysis of principal coordinates: A useful method of constrained ordination for ecology. Ecology 84(2): 511-525.

Bawa KS (1983) Patterns of flowering in tropical plants. In: Jones $\mathrm{CE}$ and Little RJ (eds) Handbook of Experimental Pollination Biology. New York: Van Nostrand Reinhold, pp. 394-410.

Bawa KS and Hadley M (eds) (1990) Reproductive Ecology of Tropical Forest Plants: Man and the Biosphere Series, vol. 7. Paris: UNESCO.

Becker A, Körner C, Brun J et al. (2007) Ecological and land use studies along elevational gradients. Mountains Research and Development 27(1): 58-65.

Behling H, Cohen MVL and Lara RJ (2001) Studies on Holocene mangrove ecosystem dynamics of the Bragança Peninsula in north-eastern Pará, Brazil. Palaeogeography, Palaeoclimatology, Palaeoecology 167: 225-242.

Birks HJB and Birks HH (1980) Quaternary Palaeoecology. London: Edward Arnold.

Bonnefille R (1971) Atlas des pollens d'Éthiopie principales espèces des forêts de Montagne. Pollen et Spores 13(1): 1572.

Bonnefille R and Riollet G (1988) The Kashiru pollen sequence (Burundi) palaeoclimatic implications for the last 40,000 yr B.P. in tropical Africa. Quaternary Research 30: 19-35.

Bonnefille R, Buchet G, Friis G et al. (1993) Modern pollen rain on an altitudinal range of forests and woodlands in South West Ethiopia. Opera Botanica 121: 71-84.

Braun-Blanquet J (1964) Pflanzensoziologie: Grundzüge der Vegetationskunde. 3rd Edition. Wien: Springer Verlag.

Bush MB (2000) Deriving response matrices from central American modern pollen rain. Quaternary Research 54: 132-143.

Bush MB and Rivera R (2001) Reproductive ecology and pollen representation among neotropical trees. Global Ecology and Biogeography 10: 359-367.

Bush MB and Weng C (2007) Introducing a new (freeware) tool for palynology. Journal of Biogeography 34(3): 377-380.

Calcote RR (1995) Pollen source area and pollen productivity: Evidence from forest hollows. Journal of Ecology 83: 591602.

Downie C, Humphries DW, Wilcockson WH et al. (1956) Geology of Kilimanjaro. Nature 178: 828-830.

Dupont LM and Wyputta U (2003) Reconstructing pathways of aeolian pollen transport to the marine sediments along the coastline of SW Africa. Quaternary Science Reviews 22(2-4): $157-174$

Elenga H, De Namur C, Vincens A et al. (2000a) Use of plots to define pollen - vegetation relationships in the densely forested ecosystems of Tropical Africa. Review of Palaeobotany and Palynology 112: 79-96.

Elenga H, Peyron O, Bonnefille R et al. (2000b) Pollen-based biome reconstruction for southern Europe and Africa 18,000 yr BP. Journal of Biogeography 27(3): 621-634.
Gajewski K, Lézine AM, Delestan A et al.; African Pollen Database (2002) Modern climate - vegetation - pollen relations in Africa and adjacent area. Quaternary Science Reviews 21: 1611-1631.

Gosling WD, Miller CS and Livingstone DA (2013) Atlas of the tropical West African pollen flora. Review of Palaeobotany and Palynology (Palynology of tropical Africa) 199: 1-135.

Gosling WD, Mayle FE, Tate NJ et al. (2009) Differentiation between Neotropical rainforest, dry forest, and savannah ecosystems by their modern pollen spectra and implications for the fossil pollen record. Review of Palaeobotany and Palynology 153(1-2): 70-85.

Hemp A (2001) Ecology of the pteridophytes on the southern slopes of Mt. Kilimanjaro. Plant Biology 3: 493-523.

Hemp A (2002) Ecology of the pteridophytes on the southern slopes of Mt. Kilimanjaro - I. Altitudinal distribution. Plant Ecology 159(2): 211-239.

Hemp A (2006a) Continuum or zonation? Altitudinal gradients in the forest vegetation of Mt. Kilimanjaro. Plant Ecology 184(1): 27-42.

Hemp A (2006b) The impact of fire on diversity, structure and composition of Mt. Kilimanjaro's vegetation. In: Spehn EM, Liberman $\mathrm{M}$ and Körner C (eds) Land Use Change and Mountain Biodiversity. Boca Raton, FL: CRC Press, pp. 51-68.

Hemp A (2006c) Vegetation of Kilimanjaro: Hidden endemics and missing bamboo. African Journal of Ecology 44(3): 305-328.

Hemp A and Beck E (2001) Erica excelsa as a fire-tolerating component of Mt. Kilimanjaro's forests. Phytocoenologia 31: 449-475.

Hooghiemstra H, Lézine A, Leroy Suzanne AG et al. (2006) Late Quaternary palynology in marine sediments: A synthesis of the understanding of pollen distribution patterns in the NW African setting. Quaternary International (Linking African palaeoenvironments and modern environments: PAGES Workshop) 148(1): 29-44.

Huntley B, Altwegg R, Barnard P et al. (2011) Modelling relationships between species spatial abundance patterns and climate. Global Ecology and Biogeography 61(6): 668-681.

Jackson ST and Kearsly JB (1998) Quantitative representation of local forest composition in forest-floor pollen assemblages. Journal of Ecology 86: 474-490.

Jackson ST and Lyford ME (1999) Pollen dispersal models in Quaternary plant ecology: Assumptions, parameters, and prescriptions. Botanical Review 65(1): 39-75.

Jackson ST and Wong A (1994) Using forest patchiness to determine pollen source areas of closed-canopy pollen assemblages. Journal of Ecology 82(1): 89-99.

Jacobson GL and Bradshaw RHW (1981) The selection of sites for palaeovegetational studies. Quaternary Research 16(1): $80-96$.

Jolly D, Prentice IC, Bonnefille R et al. (1998) Biome reconstruction from pollen and plant macrofossil data for Africa and the Arabian peninsula at 0 and 6000 years. Journal of Biogeography 25: 1007-1027.

Juggins S (2011) C2 Data Analysis. Newcastle upon Tyne: Newcastle University.

Kent M (2006) Numerical classification and ordination methods in biogeography. Progress in Physical Geography 30(3): 399-408.

Kessler M (2001) Patterns of diversity and range size of selected plant groups along an elevational transect in the Bolivian Andes. Biodiversity and Conservation 10: 1897-1920.

Körner C (2003) Alpine Plant Life: Functional Plant Ecology of High Mountain Ecosystems. Berlin: Springer Verlag.

Lebamba J, Ngomanda A, Vincens A et al. (2009) Central African biomes and forest succession stages derived from modern 
pollen data and plant functional types. Climate of the Past 5: 403-429.

Lézine AM (2001) African Pollen Database - Late Quaternary Pollen Flora. Available at: http://apd.sedoo.fr/apd/accueil. htm.

Lézine AM, Watrin J, Vincens A et al. (2009) Are modern pollen data representative of west African vegetation? Review of Palaeobotany and Palynology 156(3-4): 265-276.

McCune B, Grace JB and Urban DL (2002) Analysis of Ecological Communities. Gleneden Beach, OR: MjM Software Design.

Marchant R and Taylor D (1998) Dynamics of montane forest in central Africa during the late Holocene: A pollen-based record from western Uganda. The Holocene 8(4): 375-381.

Marchant R and Taylor D (2000) Pollen representivity of montane forest taxa in south-west Uganda. New Phytologist 146(3): $515-525$.

Marchant R, Harrison SP, Hooghiemstra H et al. (2009) Pollenbased biome reconstruction for Latin America at 0,6000 and 18000 radiocarbon years. Climate of the Past 5: 369-461.

Marchant R, Taylor D and Hamilton A (1997) Late Pleistocene and Holocene history at Mubwindi Swamp, Southwest Uganda. Quaternary Research 47: 316-328.

Marret F, Kim S and Scourse J (2013) A 30,000 yr record of land - ocean interaction in the eastern Gulf of Guinea. Quaternary Research 80(1): 1-8.

Minckley T and Whitlock C (2000) Spatial variation of modern pollen in Oregon and southern Washington, USA. Review of Palaeobotany and Palynology 112(1-3): 97-123.

Mueller-Dombois D and Ellenberg H (1974) Aims and Methods of Vegetation Ecology. New York: John Wiley \& Sons.

Müller MJ (1989) Handbuch ausgewählter Klimastationen der Erde. Trier: Forschungsstelle Bodenerosion der Universität Trier.

Niemann H, Brunschön C and Behling H (2010) Vegetation/ modern pollen rain relationship along an altitudinal transect between 1920 and $3185 \mathrm{~m}$ a.s.l. in the Podocarpus National Park region, southeastern Ecuadorian Andes. Review of Palaeobotany and Palynology 159: 69-80.

Oksanen J, Blanchet FG, Kindt R et al. (2013) vegan: Community Ecology Package: R package version 2.0-8. Available at: http://CRAN.R-project.org/package=vegan.

Prentice IC (1980) Multidimensional scaling as a research tool in quaternary palynology: A review of theory and methods. Review of Palaeobotany and Palynology 31(0): 71-104.

Prentice IC (1985) Pollen representation, source area, and basin size: Towards a unified theory of pollen analysis. Quaternary Research 23(1): 76-86.

Prentice C, Guiot J, Huntley B et al. (1996) Reconstructing biomes from palaeoecological data: A general method and its application to European pollen data at 0 and $6 \mathrm{ka}$. Climate Dynamics 12(3): 185-194.

Punyasena SW (2008) Estimating Neotropical palaeotemperature and palaeoprecipitation using plant family climatic optima. Palaeogeography, Palaeoclimatology, Palaeoecology 265(34): 226-237.

Reese CA and Liu K (2005) A modern pollen rain study from the central Andes region of South America. Journal of Biogeography 32: 709-718.

Rodgers JC III and Horn SP (1996) Modern pollen spectra from Costa Rica. Palaeogeography, Palaeoclimatology, Palaeoecology 124: 53-71.

Schüler L (2013) Studies on late Quaternary environmental dynamics (vegetation, biodiversity, climate, soils, fire and human impact) on Mt Kilimanjaro. Doctoral thesis, University of Göttingen.

Schüler L, Hemp A, Zech W et al. (2012) Vegetation, climate and fire-dynamics in East Africa inferred from the Maundi crater pollen record from Mt Kilimanjaro during the last glacialinterglacial cycle. Quaternary Science Reviews 39: 1-13.

Sugita S (1993) A model of pollen source area for an entire lake surface. Quaternary Research 39: 239-244.

Sugita S (1994) Pollen representation of vegetation in Quaternary sediments: Theory and method in patchy vegetation. Journal of Ecology 82(4): 881-897.

Tauber H (1967) Investigations of the mode of pollen transfer in forested areas. Review of Palaeobotany and Palynology 3(1-4): 277-286.

Telford RJ and Birks HJB (2005) The secret assumption of transfer functions: Problems with spatial autocorrelation in evaluating model performance. Quaternary Science Reviews 24(20-21): 2173-2179.

Urrego DH, Silman MR, Correa-Metrio A et al. (2011) Pollen - vegetation relationships along steep climatic gradients in western Amazonia. Journal of Vegetation Science 22(5): 795-806.

Vincens A, Bremond L, Brewer S et al. (2006) Modern pollenbased biome reconstructions in East Africa expanded to southern Tanzania. Review of Palaeobotany and Palynology 140(3-4): 187-212.

Vincens A, Ssemmanda I, Roux M et al. (1997) Study of the modern pollen rain in Western Uganda with a numerical approach. Review of Palaeobotany and Palynology 96(1-2): 145-168.

Watrin J, Lézine AM, Gajewski K et al. (2007) Pollen-plant-climate relationships in sub-Saharan Africa. Journal of Biogeography 34: 489-499.

Weng C, Bush MB and Silman MR (2004) An analysis of modern pollen rain on an elevational gradient in southern Peru. Journal of Tropical Ecology 20: 113-124. 